\title{
Evaluasi Perlintasan Sebidang Jalan Rel dengan Jalan Raya di Kota Semarang
}

(Studi Kasus: Perlintasan di Jalan Anjasmoro Raya, Jalan Madukoro Raya dan Jalan Kokrosono)

\author{
Narendra Dewa Bagaskara ${ }^{1}$, Galang Pringgondani ${ }^{2}$, \\ Djoko Setijowarno ${ }^{3}$, Rudatin Ruktiningsih ${ }^{4}$ \\ email: ${ }^{1}$ narendradwp@gmail.com, ${ }^{2}$ galangpringgondani@gmail.com \\ Program Studi Teknik Sipil, Fakultas Teknik \\ Universitas Katolik Soegijapranata, Semarang \\ Jl. Pawiyatan Luhur IV/1 Bendan Dhuwur Semarang 50234, 024-8441555
}

\begin{abstract}
Abstrak
Tundaan dan Antrian kendaraan cukup panjang terjadi di Jalan Anjasmoro, Madukoro, Kokrosono karena volume dari ruas jalan yang tidak bertambah yang menyebabkan penyempitan jalan sehingga menyebabkan waktu untuk melintasi ruas jalan tersebut menjadi bertambah lama. Perhitungan tundaan dan panjang antrian berdasarkan data asli dari hasil survei yang dilakukan di Jalan Anjasmoro Raya, Madukoro Raya, Kokrosono. Sedangkan perhitungan konsumsi bahan bakar berdasarkan persamaan dari LAPI-ITB yang kemudian dikonversikan menjadi satuan mobil penumpang. Analisis hubungan antara tundaan dan panjang antrian terhadap konsumsi bahan bakar dilakukan dengan cara menganalisis regresi linier berganda. Berdasarkan analisis data dan pembahasan, hasil model regresi linier berganda dengan variabel bebas berupa tundaan (X1) dan panjang antrian (X2) terhadap variabel tidak bebas yaitu konsumsi bahan bakar $(\mathrm{Y})$ adalah $\mathrm{Y}=0.012+0.389 \mathrm{X} 1+0.0008547 \mathrm{X} 2$ untuk pagi hari. Hasil analisis menunjukkan tundaan, panjang antrian tertinggi di perlintasan Madukoro Raya sebesar 273 m dikarekan memiliki jumlah tundaan yang lama dan konsumsi bbm tertinggi diperlintasan Kokrosono sebesar 300.32 liter dikarenakan memiliki tundaan yang lama, semakin tinggi nilai waktu tundaan dan panjang antrian semakin besar pula konsumsi bahan bakar yang terbuang. Berdasarkan ketentuan SK 770 tahun 2005 (LHR x frekuensi kereta api < $35.000 \mathrm{smpk}$ ) pada perlintasan Anjasmoro Raya (2.580.614,4 smpk), Madukoro Raya (2.718.034,8 smpk), Kokrosono (1.173.984,3 smpk) sudah tidak memenuhi syarat sebagai perlintasan sebidang, sehingga sebaiknya sudah ditingkatkan menjadi perlintasan tidak sebidang seperti fly over, dll.pengaruh terhadap konsumsi bahan bakar, artinya semakin tinggi nilai waktu tundaan dan panjang antrian semakin besar pula konsumsi bahan bakar yang terbuang.
\end{abstract}

Kata Kunci: Tundaan, Antrian, Konsumsi BBM, Waktu

\begin{abstract}
Delays and queues of vehicles are quite long going on Jalan Anjasmoro, Madukoro, Kokrosono because the volume of the road does not increase which causes narrowing of the road, causing time to cross the road to become longer. Calculation of delay and queue length based on original data from the results of a survey conducted at Jalan Anjasmoro Raya, Madukoro Raya, Kokrosono. While the calculation of fuel consumption is based on the equation of LAPI-ITB which is then converted into passenger car units. Analysis of the relationship between delay and queue length on fuel consumption is done by analyzing multiple linear regression. Based on data analysis and discussion, the results of multiple linear regression models with independent variables in the form of delay (X1) and queue length (X2) for non-independent variables, namely fuel consumption $(Y)$ is $Y=0.012+0.389 X 1+0.0008547 X 2$ for the morning. The
\end{abstract}


analysis shows the delay, the highest queue length at the Madukoro Raya crossing of $273 \mathrm{~m}$ because it has a long delay and the highest fuel consumption is Kokrosono crossing of 300.32 liters due to the long delay, the higher delay time and queue length the greater the fuel consumption wasted. Based on the provisions of SK 770 of 2005 (LHR x train frequency $<35,000$ рси) at Anjasmoro Raya crossing (2,580,614.4 junior high), Madukoro Raya (2,718,034.8 junior high), Kokrosono (1,173,984.3 junior high) does not fulfill the requirements as a level crossing, so it should have been upgraded to crossing not as large as fly over, etc. the effect on fuel consumption, meaning that the higher the time value of the delay and the length of the queue the greater the wasted fuel consumption.

Keyword: Delay, Queue, Fuel Consumption, Time

\section{PENDAHULUAN}

\subsection{Latar belakang}

Indonesia memiliki kepadatan penduduk yang selalu meningkat yang berdampak pada beberapa faktor pertumbuhan dan perkembangan yaitu faktor ekonomi, faktor sosial dan faktor budaya. Pertumbuhan penduduk pada suatu negara juga dapat mengakibatkan meningkatnya suatu pergerakan dari barang atau manusia dari satu tempat ke tempat lainnya yang semakin banyak setiap harinya. Transportasi semakin hari semakin meningkat dan canggih seiring berjalannya waktu dengan meningkatnya pertumbuhan dan perkembangan dari penduduk pada suatu negara. Moda transportasi sendiri pada umumnya dikelompokkan menjadi 3 bagian yaitu moda transportasi darat, transportasi laut, dan transportasi udara.

Moda transportasi darat sendiri dibagi menjadi 2 berdasarkan dari tracknya yaitu moda transportasi jalan raya, dan moda transportasi jalan rel. Moda transportasi atau kereta api memiliki keunggulan tersendiri yaitu memiliki jalur khusus yang bebas hambatan dan tidak terpengaruh dengan laju dari kendaraan lainnya, sehingga moda transportasi kereta api lebih banyak diminati oleh masyarakat karena mampu menempuh jarak yang jauh dengan waktu yang singkat dan lebih aman dibandingkan moda transportasi jalan raya.
Di Indonesia sendiri sudah banyak dijumpai perlintasan kereta api jalan rel yang berpotongan langsung dengan jalan raya yang pada umumnya biasa disebut dengan perlintasan sebidang.

\subsection{Lokasi Proyek dan Data Teknis}

Di kota Semarang sendiri sangat banyak ditemui perlintasan dari kereta api yang sebidang dengan jalan raya, dan kebanyakan di kota Semarang sendiri sudah banyak terdapat lintasan rel kereta api yang sudah menggunakan jalur double track.

Rata - rata di kota Semarang perlintasan sebidang antara jalur dari rel kereta api dan jalan raya sudah banyak yang menggunakan pintu palang penutup otomatis, dan ada beberapa perlintasa sebidang yang masih belum menggunakan palang pintu otomatis.

Seharusnya semua perlintasan yang sebidang harus dilengkapi dengan pintu palang otomatis mengingat di kota Semarang rata - rata jalur dari kereta api sudah menggunakan double track semua. Akan tetapi palang pintu otomatis disamping sangat baik dari faktor keselamatan, juga memiliki kelemahan yaitu saat palang otomatis mulai menutup maka akan ada penumpukan volume kendaraan, penurunan kecepatan kendaraan, dan kepadatan dari kendaraan yang sangat panjang. 
Rata - rata pengemudi di Indonesia lebih memilih mengutamakan waktu dibanding dengan keselamatannya sendiri. Hal inilah mengapa masyarakat Indonesia lebih banyak memilih menggunakan moda transportasi kereta api, dikarenakan cepat sampai tujuan, dan sangat sedikit kasus kecelakaan kereta api.

\subsection{Tujuan Penelitian}

Tujuan dari Penelitian ini adalah :

1. Mengetahui kondisi eksisting dari perlintasan sebidang di Jalan Anjasmoro Raya, Jalan Madukoro Raya, dan Jalan Krokosono.

2. Mengevaluasi kondisi tundaan kendaraan, dan antrian dari kendaraan yang melalui perlintasan sebidang tersebut dengan menggunakan teori Queueing Analysis.

3. Mengetahui jumlah Bahan Bakar Minyak yang terbuang selama terjadinya tundaan dan antrian pada perlintasan sebidang tersebut.

\subsection{Manfaat Penelitian}

Manfaat dari Penelitian ini adalah :

1. Merupakan salah satu masukan bagi PT. KAI dan Dinas Perhubungan kota Semarang dan Provinsi Jawa Tengah sebagai salah satu alternatif penyelesaian dari masalah yang ada pada perlintasan sebidang tersebut.

2. Memberikan tambahan wawasan dan pengetahuan kepada masyarakat tentang manajemen lalu lintas yang khususnya mengenai perlintasan sebidang.

3. Memberikan sedikit wawasan bagi warga kota Semarang dan negara Indonesia bahwa begitu banyaknya bahan bakar minyak yang terbuang selama terjadinya tundaan dan antrian pada saat kereta melintas.

\subsection{Batasan Masalah}

Agar penelitian ini lebih terarah, maka dilakukan berdasarkan dengan beberapa batasan masalah yaitu :
1. Penelitian ini dilakukan pada perlintasan sebidang yang memiliki penutup palang rel otomatis seperti di Jalan Anjasmoro Raya, Jalan Madukoro Raya, dan Jalan Kokrosono, Semarang.

2. Melakukan evaluasi terhadap tundaan dari kendaraan, dan antrian dari kendaraan dari kendaraan dengan menggunakan teori Queueing Analysis.

3. Melakukan evaluasi terhadap bahan bakar minyak yang terbuang selama terjadinya tundaan dan antrian pada saat palang kereta api menutup.

\section{TINJAUAN PUSTAKA}

Menurut Soejachmoen (2004) pembagian hirarki ini sebagai berikut prioritas utama pengguna jalan yang harus diberikan kepada pejalan kaki, yang artinya pengguna transportasi lain diwajibkan mendahulukan pengguna jalan.

Menurut penelitian dari Setianingsih (2007) pelintasan sebidang antara jalan raya dengan jalan rel kereta api adalah suatu kasus yang khusus pada ruas jalan raya dengan tanggung jawab dalam pengaturan dan pertimbangan dari keamanan yang terbagi untuk kepentingan jalan raya dan jalan rel kereta api.

\section{Berdasarkan Peraturan}

Direktorat Jenderal Perhubungan Darat, Pedoman Teknis Perlintasan Sebidang Antara Jalan Raya dengan Jalan Kereta Api yang dikeluarkan oleh Dinas Perhubungan pada tahun 2005 maupun Perencanaan Perlintasan Jalan dengan Jalan Kereta Api oleh Departemen Pemukiman dan Prasarana Wilayah tahun 2004, ada 2 ketentuan dalam perencanaan perlintasan sebidang yaitu:

1. Ketentuan Umum

Dalam pedoman perlintasan jalan dengan jalur kereta api harus 
memperhatikan aspek - aspek sebagai berikut:

a. Keselamatan lalu lintas, dimana kereta api mempunyai prioritas yang utama.

b. Pandangan bebas dari pemakai jalan.

c. Kepentingan dari pejalan kaki utama.

d. Drainase jalan yang lancar.

e. Menyangkut kepentingan dari penyandang cacat.

f. Desain yang ramah terhadap lingkungan.

2. Ketentuan Teknis

a. Geometrik pada perlintasan sebidang (sarana dan prasarana, klasifikasi, fungsi jalan, potongan melintang dan daerah / ruang bebas).

b. Pengaturan dari lalu lintas.

c. Tipe perkerasan pada perlintasan sebidang.

Persyaratan penyelenggaraan persilangan perlintasan sebidang antara jalan raya dengan kereta api mengacu kepada Peraturan Direktur Jenderal Perhubunga Darat Nomor SK.770/KA.401/DRJD/2005 tentang Pedoman Teknis Perlintasan Sebidang Antara Jalan dengan Jalur Kereta Api. Didalam peraturan tersebut serta mengacu pada peraturan perundangan yang lebih tinggi, maka perlintasan antara jalan dengan jalur kereta api dibuat dengan prinsip yang tidak sebidang.

\section{METODOLOGI PENELITIAN}

Pada penelitian ini mengambil objek Perlintasan Sebidang di Kota Semarang. Lokasi yang terpilih dalam penelitian ini terdapat di tiga lokasi perlintasan sebidang yang akan diteliti yaitu Jalan Madukoro Raya seperti pada gamabar 3.1, Jalan Kokrosono Raya seperti pada gambar 3.2, Jalan
Anjasmoro Raya seperti pada gambar 3.3.

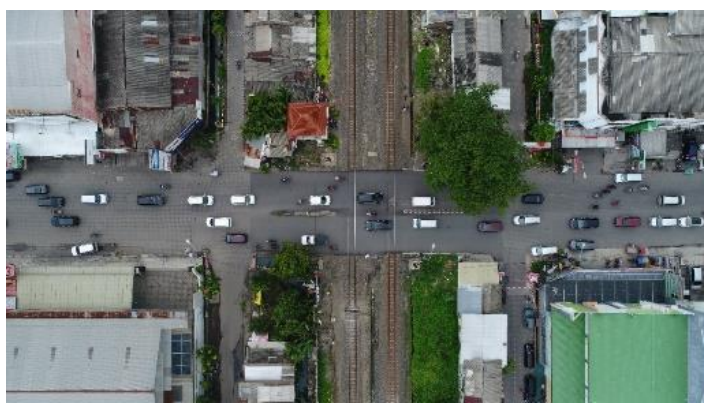

Gambar 3.1 Lokasi Perlintasan

Sebidang Jalan Anjasmoro Raya

Sumber : Hasil Survey 2018

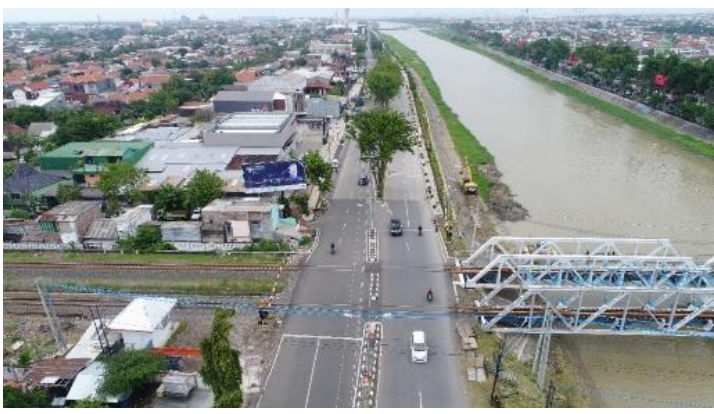

Gambar 3.2 Lokasi Perlintasan

Sebidang Jalan Madukoro Raya

Sumber : Hasil Survey 2018

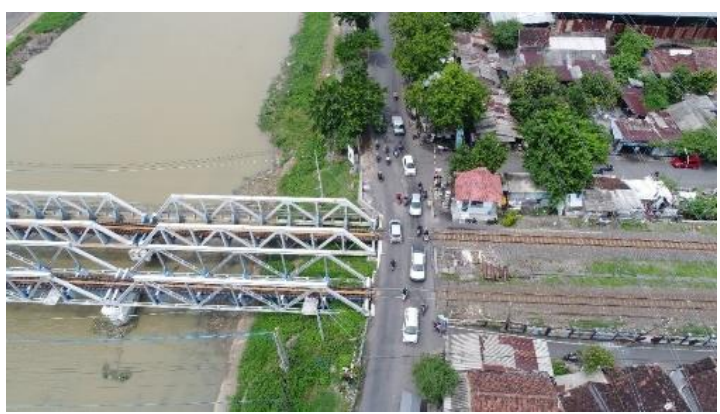

Gambar 3.3 Lokasi Perlintasan

Sebidang Jalan Kokrosono

Sumber : Hasil Survey 2018

Alasan pemilihan perlintasan sebidang di Jalan Madukoro Raya, Jalan Kokrosono, dan Jalan Anjasmoro Raya sebagai lokasi penelitian dikarenakan perlintasan ini merupakan perlintasan yang banyak dilalui oleh warga sekitar untuk menuju pusat perbelanjaan, kantor, dan sekolah atau universitas. 
Data primer didapat dengan langsung melakukan survei ke lokasi penelitian di Jalan Madukoro Raya, Jalan Kokrosono Raya, dan Jalan Anjasmoro Raya. Periode pengamatan di lapangan dilakukan pada hari yang ditetapkan selama 12 jam.

Data yang didapat dari hasil pengamatan :

1. Volume arus lalu lintas, data volume lalu lintas pada ruas Jalan Madukoro Raya, Jalan Kokrosono Raya, dan Jalan Anjasmoro Raya dihitung untuk semua jenis kendaraan selama 12 jam.

2. Waktu kereta api melintas, selama penelitian surveyor mencatat jam kereta api melintas pada perlintasan di Jalan Madukoro Raya, Jalan Kokrosono Raya, dan Jalan Anjasmoro Raya.

3. Durasi Penutupan Pintu, data durasi penutupan pintu perlintasan kereta api diperoleh dengan mencatat waktu pada saat pintu perlintasan mulai ditutup sebesar 450 sampai pada saat pintu perlintasan dibuka sebesar 450, sehingga selisih dari waktu tersebut diperoleh durasi penutupan pintu perlintasan.

4. Jumlah kendaraan dalam antrian dan panjang antrian, pada saat perlintasan mulai ditutup maka surveyor menghitung jumlah kendaraan yang barada dalam antrian dan mengukur panjangnya antrian pada ruas jalan.

5. Waktu Pemulihan lalu lintas Akibat penutupan Perlintasan, survei data waktu pemulihan akibat penutupan perlintasan dihitung mulai pada saat pintu perlintasan dibuka sampai dengan kondisi lalu lintas normal kembali.

Bagan Alir

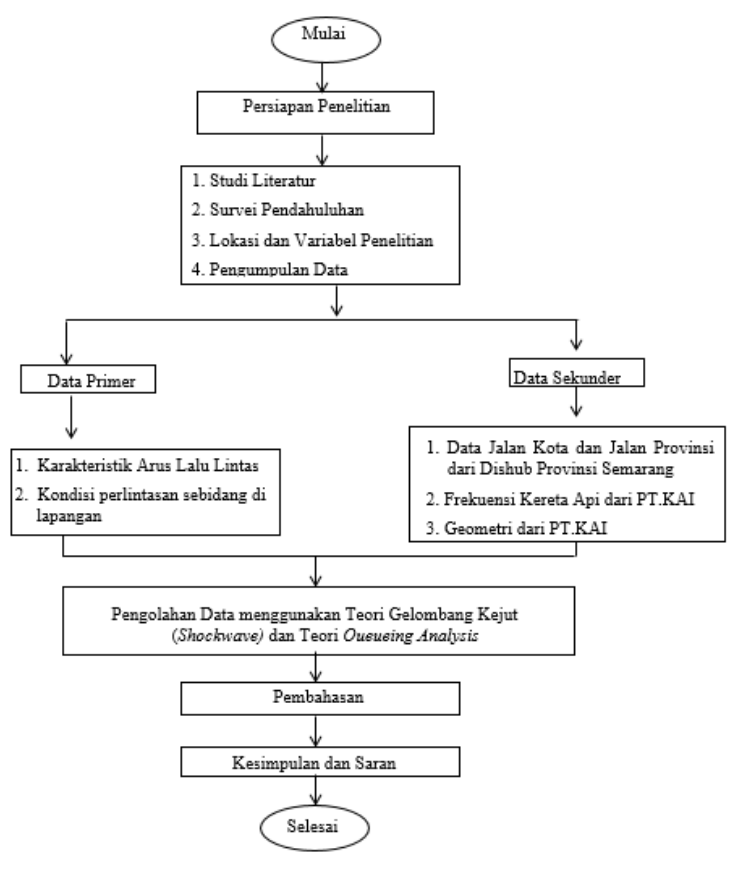

4. HASIL DAN PEMBAHASAN 4.1. Perlintasan Anjasmoro Raya

\subsubsection{Volume Perlintasan Anjasmoro Raya}

\begin{tabular}{|c|c|c|c|c|c|c|}
\hline Waktu & $\begin{array}{c}\text { EMP } \\
\text { motor }\end{array}$ & $\begin{array}{c}\text { EMP } \\
\text { Mobil }\end{array}$ & $\begin{array}{c}\text { EMP } \\
\text { Kendaraan } \\
\text { Berat }\end{array}$ & $\begin{array}{c}\text { EMP } \\
\text { Angkutan } \\
\text { Umum }\end{array}$ & $\begin{array}{c}\text { EMP } \\
\text { Kendaraan } \\
\text { tak } \\
\text { bermotor }\end{array}$ & $\begin{array}{c}\text { Jumlah } \\
\text { EMP }\end{array}$ \\
\hline $06.00-07.00$ & 319,00 & 580,38 & 0,75 & 3,60 & 4,75 & 908,48 \\
\hline $07.00-08.00$ & 414,75 & 702,50 & 4,60 & 6,30 & 5,50 & 1133,65 \\
\hline $08.00-09.00$ & 385,20 & 634,50 & 4,55 & 5,60 & 1,70 & 1031,55 \\
\hline $09.00-10.00$ & 407,55 & 612,00 & 5,10 & 5,35 & 2,40 & 1032,40 \\
\hline $10.00-11.00$ & 397,35 & 755,50 & 4,05 & 4,50 & 1,95 & 1163,35 \\
\hline $11.00-12.00$ & 420,00 & 782,63 & 3,60 & 4,10 & 2,10 & 1212,43 \\
\hline $12.00-13.00$ & 452,20 & 825,38 & 3,00 & 4,15 & 1,95 & 1286,68 \\
\hline $13.00-14.00$ & 439,05 & 715,00 & 4,75 & 5,20 & 4,40 & 1168,40 \\
\hline $14.00-15.00$ & 470,00 & 714,50 & 5,90 & 6,05 & 4,85 & 1201,30 \\
\hline $15.00-16.00$ & 527,05 & 774,63 & 5,15 & 6,10 & 5,70 & 1318,63 \\
\hline $16.00-17.00$ & 527,55 & 765,38 & 2,00 & 3,55 & 2,20 & 1300,68 \\
\hline $17.00-18.00$ & 478,80 & 736,13 & 0,40 & 0,60 & 0,15 & 1216,08 \\
\hline
\end{tabular}

\section{Sumber : Hasil Survey Perlintasan} Anjasmoro Raya,2018

Dari data yang di peroleh pada saat survey di lapangan, dapat di peroleh hasil lalu lintas harian rata rata (LHR) diperlintasan anjasmoro raya sebesar 27,947.20 smp/jam. Hasil perkalian LHR dengan frekuensi kereta api sebesar 2,850,614.40 smpk. Volume 
maksimal terjadi pada pukul 15.00 16.00 sebesar 1,318.68 smp.

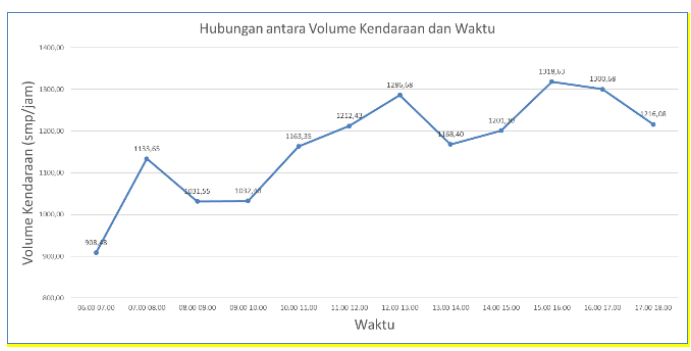

Gambar 4.8 Diagram garis hubungan volume kendaraan dan waktu pada perlintasan Anjasmoro Raya Sumber : Hasil Survey Perlintasan Anjasmoro Raya,2018

\subsubsection{Tundaan Perlintasan Anjasmoro Raya}

\begin{tabular}{|c|c|c|c|c|c|}
\hline No & $\begin{array}{c}\text { Jam Kedatangan } \\
\text { Kereta Api }\end{array}$ & tundaaan (detik) & No & $\begin{array}{c}\text { Jam Kedatangan } \\
\text { Kereta Api }\end{array}$ & tundaaan (detik) \\
\hline \hline 1 & $6: 02$ & 82 & 24 & $11: 49$ & 87 \\
\hline 2 & $6: 09$ & 89 & 25 & $12: 02$ & 92 \\
\hline 3 & $6: 17$ & 115 & 26 & $12: 24$ & 110 \\
\hline 4 & $6: 37$ & 108 & 27 & $12: 53$ & 128 \\
\hline 5 & $6: 48$ & 108 & 28 & $13: 07$ & 112 \\
\hline 6 & $7: 05$ & 104 & 29 & $13: 20$ & 115 \\
\hline 7 & $7: 18$ & 119 & 30 & $13: 25$ & 151 \\
\hline 8 & $7: 24$ & 189 & 31 & $13: 36$ & 109 \\
\hline 9 & $7: 32$ & 159 & 32 & $13: 57$ & 155 \\
\hline 10 & $7: 47$ & 138 & 33 & $14: 04$ & 91 \\
\hline 11 & $8: 14$ & 105 & 34 & $14: 23$ & 139 \\
\hline 12 & $8: 17$ & 110 & 35 & $14: 41$ & 127 \\
\hline 13 & $8: 22$ & 114 & 36 & $14: 44$ & 207 \\
\hline 14 & $8: 38$ & 106 & 37 & $15: 02$ & 150 \\
\hline 15 & $9: 00$ & 117 & 38 & $15: 14$ & 164 \\
\hline 16 & $9: 15$ & 108 & 39 & $15: 17$ & 125 \\
\hline 17 & $9: 26$ & 122 & 40 & $15: 57$ & 155 \\
\hline 18 & $9: 50$ & 100 & 41 & $16: 07$ & 103 \\
\hline 19 & $10: 13$ & 97 & 42 & $16: 16$ & 124 \\
\hline 20 & $10: 30$ & 101 & 43 & $16: 34$ & 138 \\
\hline 21 & $10: 51$ & 138 & 44 & $17: 02$ & 120 \\
\hline 22 & $11: 15$ & 119 & 45 & $17: 23$ & 110 \\
\hline 23 & $11: 39$ & 99 & 46 & $17: 49$ & 115 \\
\hline
\end{tabular}

Sumber : Hasil Survey (2018)

Berdasarkan hasil survei pada perlintasan anjasmoro raya diperoleh rata-rata waktu tundaan. Pada tabel 4.23 diatas dapat terlihat tundaan terlama terjadi yaitu 207 detik pada pukul 14:44
4.1.3. Panjang Antrian Perlintasan Anjasmoro Raya

\begin{tabular}{|c|c|c|c|c|c|}
\hline \multirow{2}{*}{$\begin{array}{c}\text { Jam Kedatangan } \\
\text { Kereta Api }\end{array}$} & \multicolumn{2}{|c|}{ panjang antrian } & \multirow{2}{*}{$\begin{array}{c}\text { Jam Kedatangan } \\
\text { Kereta Api }\end{array}$} & \multicolumn{2}{|c|}{ panjang antriar } \\
\hline & selatan & utara & & selatan & utara \\
\hline 6:02 & 10 & 15 & 11:49 & 15 & 20 \\
\hline $6: 09$ & 18 & 22 & 12:02 & 21 & 25 \\
\hline $6: 17$ & 21 & 48 & 12:24 & 39 & 43 \\
\hline $6: 37$ & 35 & 41 & $12: 53$ & 55 & 61 \\
\hline $6: 48$ & 40 & 41 & 13:07 & 42 & 45 \\
\hline $7: 05$ & 33 & 37 & $13: 20$ & 36 & 48 \\
\hline $7: 18$ & 44 & 52 & $13: 25$ & 24 & 84 \\
\hline $7: 24$ & 73 & 122 & 13:36 & 36 & 42 \\
\hline $7: 32$ & 61 & 92 & 13:57 & 80 & 88 \\
\hline $7: 47$ & 46 & 71 & 14:04 & 32 & 24 \\
\hline $8: 14$ & 35 & 38 & $14: 23$ & 48 & 72 \\
\hline $8: 17$ & 15 & 43 & 14:41 & 60 & 60 \\
\hline $8: 22$ & 20 & 47 & $14: 44$ & 77 & 140 \\
\hline $8: 38$ & 29 & 39 & $15: 02$ & 40 & 83 \\
\hline 9:00 & 21 & 50 & $15: 14$ & 24 & 97 \\
\hline $9: 15$ & 18 & 41 & $15: 17$ & 32 & 58 \\
\hline $9: 26$ & 33 & 55 & $15: 57$ & 32 & 88 \\
\hline $9: 50$ & 30 & 33 & $16: 07$ & 47 & 36 \\
\hline 10:13 & 26 & 30 & $16: 16$ & 52 & 57 \\
\hline 10:30 & 29 & 34 & $16: 34$ & 66 & 71 \\
\hline 10:51 & 33 & 71 & $17: 02$ & 49 & 53 \\
\hline 11:15 & 22 & 52 & $17: 23$ & 38 & 43 \\
\hline $11: 39$ & 25 & 32 & $17: 49$ & 45 & 48 \\
\hline
\end{tabular}

Sumber : Hasil Survey (2018)

Berdasarkan hasil survei pada perlintasan anjasmoro raya diperoleh rata-rata waktu panjang antrian. Pada tabel 4.24 diatas dapat terlihat panjang antrian terlama terjadi pada pukul 14.44. Dengan panjang 77 meter dari arah selatan dan 120 meter dari arah utara dengan jumlah sepeda motor paling dominan.

\subsubsection{Konsumsi BBM Perlintasan Anjasmoro Raya}

\begin{tabular}{|c|c|c|c|c|}
\hline No & $\begin{array}{c}\text { Jam Kedatangan } \\
\text { Kereta Api }\end{array}$ & $\begin{array}{c}\text { Tundaan } \\
\text { (detik) }\end{array}$ & $\begin{array}{c}\text { Antrian } \\
(\mathrm{m})\end{array}$ & $\begin{array}{c}\text { Konsumsi BBM } \\
\text { (Liter) }\end{array}$ \\
\hline 1 & 06:00:00 - 07:00:00 & 502 & 291 & 195.54 \\
\hline 2 & 07:00:00 - 08:00:00 & 709 & 631 & 276.35 \\
\hline 3 & 08:00:00 - 09:00:00 & 435 & 266 & 169.45 \\
\hline 4 & 09:00:00 - 10:00:00 & 447 & 281 & 174.14 \\
\hline 5 & 10:00:00 - 11:00:00 & 336 & 223 & 130.91 \\
\hline 6 & 11:00:00 - 12:00:00 & 305 & 166 & 118.80 \\
\hline 7 & $12: 00: 00$ - 13:00:00 & 330 & 244 & 128.59 \\
\hline 8 & $13: 00: 00$ - 14:00:00 & 642 & 525 & 250.20 \\
\hline 9 & 14:00:00 - 15:00:00 & 564 & 513 & 219.85 \\
\hline 10 & 15:00:00 - 16:00:00 & 594 & 454 & 231.47 \\
\hline 11 & $16: 00: 00$ - 17:00:00 & 365 & 329 & 142.28 \\
\hline 12 & $17: 00: 00$ - 18:00:00 & 345 & 276 & 134.45 \\
\hline \multicolumn{4}{|c|}{ Total Konsumsi Bahan Bakar Minyak / jam (Liter) } & 2172.02 \\
\hline
\end{tabular}

Sumber : Hasil Survey (2018)

Berdasarkan table 2.26 di atas jumlah pengeluaran konsumsi bbm tertinggi pada pukul $07.00-08.00$ 
sebesar 276.35 liter sedangkan yang terendah pada pukul 11.00 - 12.00 sebesar 118.80 liter.

\subsubsection{Perbandingan antara} persyaratan perlintasan sebidang dengan kondisi perlintasan kereta api Anjasmoro

\begin{tabular}{|c|c|c|}
\hline $\mathrm{No}$ & $\begin{array}{l}\text { Persyaratan } \\
\text { Perlintasan } \\
\text { Sebidang }\end{array}$ & $\begin{array}{l}\text { Perlintasan } \\
\text { Kereta Api } \\
\text { Anjasmoro }\end{array}$ \\
\hline 1 & $\begin{array}{lr}\text { selang } & \text { waktu } \\
\text { antara } & \text { kereta } \\
\text { api satu dengan } & \text { kereta } \\
\text { berikutnya } \\
\text { (Head } \\
\text { yang may) } \\
\text { pada lokntas } \\
\text { tersebut rata- } \\
\text { rata sekurang- } \\
\text { kurangnya } 6 \\
\text { (enam) menit } \\
\text { pada waktu } \\
\text { sibuk (peak) }\end{array}$ & $\begin{array}{l}\text { selang waktu } \\
\text { antara kereta } \\
\text { api satu dengan } \\
\text { kereta api } \\
\text { berikutnya } \\
\text { (Head way) } \\
\text { yang melintas } \\
\text { pada } \\
\text { perlintasan } \\
\text { Anjasmoro } \\
\text { adalah } 5 \text { menit }\end{array}$ \\
\hline 2 & $\begin{array}{lr}\text { jarak } & \\
\text { perlintasan } & \\
\text { yang } & \text { satu } \\
\text { dengan yang } & \text { lainnya pada } \\
\text { satu jalur kereta } \\
\text { api } \\
\text { kurang dari } 800 \\
\text { meter; }\end{array}$ & $\begin{array}{l}\text { jarak } \\
\text { perlintasan } \\
\text { terdekat kurang } \\
\text { lebih adalah } \\
1.125 \text { meter }\end{array}$ \\
\hline 3 & $\begin{array}{l}\text { tidak terletak } \\
\text { pada } \\
\text { lengkungan } \\
\text { jalan kereta api } \\
\text { atau tikungan } \\
\text { jalan; }\end{array}$ & $\begin{array}{l}\text { terletak } \\
\text { kondisi } \\
\text { lurus }\end{array}$ \\
\hline 4 & $\begin{array}{l}\text { terdapat kondisi } \\
\text { lingkungan } \\
\text { yang } \\
\text { memungkinkan } \\
\text { pandangan bagi }\end{array}$ & $\begin{array}{l}\text { Tidak ada } \\
\text { bangunan } \\
\text { ataupun pohon } \\
\text { yang } \\
\text { menghalangi }\end{array}$ \\
\hline
\end{tabular}

masinis kereta jarak pandang api dari as pengguna jalan perlintasan dan bagi pengemudi kendaraan bermotor;

5 Jalan yang Jalan melintas adalah Anjasmoro jalan Kelas III termasuk ke dalam kelas III

Sumber : Tugas Akhir Gita Mustika

Dewi Kelo, Gloryani F.N Jehudu

Dari tabel 4.35 diatas, Perlintasan Anjasmoro Raya memenuhi 4 dari 5 persyaratan perlintasan sebidang. Persyaratan yang belum dipenuhi adalah ketentuan tentang waktu head way antara kereta satu dengan kereta lainnya terlalu sebentar yaitu 5 menit.

\subsubsection{Penentuan Perlintasan Sebidang Anjasmoro}

\begin{tabular}{lll}
\hline No & Penentuan & Perlintasan \\
& Perlintasan & Anjasmoro \\
& Sebidang & \\
\end{tabular}

1 Jumlah kereta Jumlah kereta api yang api yang melintas pada melintas lokasi tersebut sebanyak 88 sebanyak- kereta/hari banyaknya 25

kereta /hari;

2 Volume lalu Volume lalu lintas harian lintas harian rata-rata (LHR) rata-rata sebanyak- (LHR) sebesar banyaknya 27.947,2 1000 kendaraan smp/jam pada jalan dalam kota dan 300 kendaraan pada jalan luar 
kota

3 Hasil perkalian antara volume lalu lintas harian rata-rata (LHR) dengan frekuensi kereta api sebanyakbanyaknya $12.500 \mathrm{smpk}$.
Hasil perkalian antara volume lalu lintas harian rata- rata dengan frekuensi kereta api sebanyak 2.80.614,4 smpk

Sumber : Tugas Akhir Gita Mustika Dewi Kelo, Gloryani F.N Jehudu

Perlintasan Anjasmoro sudah memenuhi untuk menjadi perlintasan sebidang dengan palang pintu. Karena baik dari frekuensi kereta api, maupun LHR dan hasil perkalian LHR dengan frekuensi kereta api sudah memenuhi syarat sebagai perlintasan sebidang dengan palang pintu.

\subsection{Perlintasan Madukoro Raya}

\subsubsection{Volume Perlintasan Madukoro Raya}

\begin{tabular}{|c|c|c|c|c|c|c|}
\hline Waktu & $\begin{array}{c}\text { EMP } \\
\text { motor }\end{array}$ & $\begin{array}{c}\text { EMP } \\
\text { Mobil }\end{array}$ & $\begin{array}{c}\text { EMP } \\
\text { Kendaraan } \\
\text { Berat }\end{array}$ & $\begin{array}{c}\text { EMP } \\
\text { Angkutan } \\
\text { Umum }\end{array}$ & $\begin{array}{c}\text { EMP } \\
\text { Kendaraan } \\
\text { tak bermotor }\end{array}$ & $\begin{array}{c}\text { Jumlah } \\
\text { EMP }\end{array}$ \\
\hline $06.00-07.00$ & 243.65 & 331.00 & 1.30 & 2.90 & 2.30 & 581.15 \\
\hline $07.00-08.00$ & 356.85 & 566.75 & 3.05 & 3.90 & 2.60 & 933.15 \\
\hline $08.00-09.00$ & 358.70 & 628.13 & 2.95 & 4.85 & 1.85 & 996.48 \\
\hline $09.00-10.00$ & 344.90 & 675.38 & 3.65 & 4.45 & 1.05 & 1029.43 \\
\hline $10.00-11.00$ & 422.95 & 734.50 & 2.85 & 3.00 & 0.80 & 1164.10 \\
\hline $11.00-12.00$ & 404.55 & 859.25 & 2.80 & 4.10 & 1.55 & 1272.25 \\
\hline $12.00-13.00$ & 432.65 & 788.88 & 3.30 & 4.25 & 2.10 & 1231.18 \\
\hline $13.00-14.00$ & 411.00 & 828.63 & 5.15 & 5.00 & 3.45 & 1253.23 \\
\hline $14.00-15.00$ & 426.90 & 808.63 & 6.05 & 5.60 & 4.70 & 1251.88 \\
\hline $15.00-16.00$ & 398.80 & 785.38 & 4.20 & 4.05 & 3.55 & 1195.98 \\
\hline $16.00-17.00$ & 423.35 & 783.38 & 3.50 & 3.75 & 2.25 & 1216.23 \\
\hline $17.00-18.00$ & 404.15 & 791.38 & 1.05 & 1.00 & 1.10 & 1198.68 \\
\hline
\end{tabular}

\section{Sumber : Hasil Survey Perlintasan} Madukoro Raya, 2018

Dari data yang di peroleh pada saat survey di lapangan, dapat di peroleh hasil lalu lintas harian rata rata (LHR) diperlintasan madukoro raya sebesar 26,647.40 smp/jam. Hasil perkalian LHR dengan frekuensi kereta api sebesar 2,718,034.80 smpk. Volume maksimal terjadi pada pukul 13.00 14.00 sebesar $1,253.23 \mathrm{smp}$.

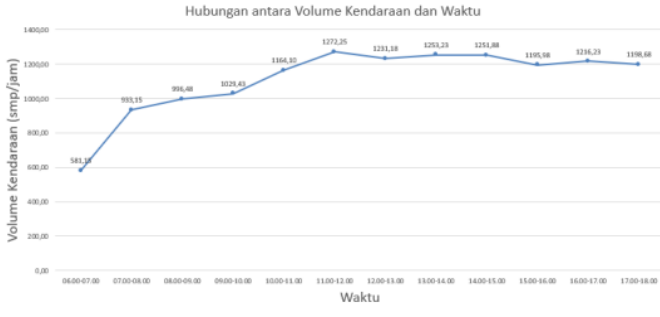

Gambar 4.10 Diagram garis hubungan volume kendaraan dan waktu pada perlintasan madukoro raya Sumber : Hasil Survey Perlintasan Madukoro Raya,2018

\subsubsection{Tundaan Perlintasan Madukoro Raya}

\begin{tabular}{|c|c|c|c|c|c|}
\hline No & $\begin{array}{c}\text { Jam Kedatangan } \\
\text { Kereta Api }\end{array}$ & tundaaan ( detik) & No & $\begin{array}{c}\text { Jam Kedatangan } \\
\text { Kereta Api }\end{array}$ & tundaaan ( detik) \\
\hline \hline 1 & $6: 06$ & 85 & 24 & $11: 53$ & 90 \\
\hline 2 & $6: 13$ & 92 & 25 & $12: 06$ & 95 \\
\hline 3 & $6: 21$ & 118 & 26 & $12: 28$ & 113 \\
\hline 4 & $6: 41$ & 111 & 27 & $12: 57$ & 131 \\
\hline 5 & $6: 52$ & 111 & 28 & $13: 11$ & 115 \\
\hline 6 & $7: 09$ & 107 & 29 & $13: 24$ & 118 \\
\hline 7 & $7: 22$ & 122 & 30 & $13: 29$ & 154 \\
\hline 8 & $7: 28$ & 192 & 31 & $13: 40$ & 112 \\
\hline 9 & $7: 36$ & 162 & 32 & $14: 01$ & 158 \\
\hline 10 & $7: 51$ & 141 & 33 & $14: 08$ & 94 \\
\hline 11 & $8: 18$ & 108 & 34 & $14: 27$ & 142 \\
\hline 12 & $8: 21$ & 113 & 35 & $14: 45$ & 130 \\
\hline 13 & $8: 26$ & 117 & 36 & $14: 48$ & 210 \\
\hline 14 & $8: 42$ & 109 & 37 & $15: 06$ & 153 \\
\hline 15 & $9: 04$ & 120 & 38 & $15: 18$ & 167 \\
\hline 16 & $9: 19$ & 111 & 39 & $15: 21$ & 128 \\
\hline 17 & $9: 30$ & 125 & 40 & $16: 01$ & 158 \\
\hline 18 & $9: 54$ & 103 & 41 & $16: 11$ & 106 \\
\hline 19 & $10: 17$ & 100 & 42 & $16: 20$ & 127 \\
\hline 20 & $10: 34$ & 104 & 43 & $16: 38$ & 141 \\
\hline 21 & $10: 55$ & 141 & 44 & $17: 06$ & 123 \\
\hline 22 & $11: 19$ & 122 & 45 & $17: 27$ & 113 \\
\hline 23 & $11: 43$ & 102 & 46 & $17: 53$ & 118 \\
\hline
\end{tabular}

Sumber : Hasil Survey (2018)

Berdasarkan hasil survei pada perlintasan madukoro raya diperoleh rata-rata waktu tundaan. Pada tabel 4.25 diatas dapat terlihat tundaan terlama terjadi yaitu 210 detik pada pukul 14:48 
4.2.3. Panjang Antrian Perlintasan Madukoro Raya

\begin{tabular}{|c|c|c|c|c|c|}
\hline \multirow{2}{*}{$\begin{array}{c}\text { Jam Kedatangan } \\
\text { Kereta Api }\end{array}$} & \multicolumn{2}{|c|}{ panjang antrian } & \multirow{2}{*}{ Jam Kedatangan } & \multicolumn{2}{|c|}{ panjang antrian } \\
\cline { 6 - 6 } Kelatan & utara & Kereta Api & selatan & utara \\
\hline \hline $6: 06$ & 32 & 27 & $11: 53$ & 109 & 80 \\
\hline $6: 13$ & 45 & 41 & $12: 06$ & 187 & 154 \\
\hline $6: 21$ & 36 & 30 & $12: 28$ & 247 & 210 \\
\hline $6: 41$ & 41 & 35 & $12: 57$ & 221 & 177 \\
\hline $6: 52$ & 108 & 85 & $13: 11$ & 176 & 135 \\
\hline $7: 09$ & 79 & 70 & $13: 24$ & 198 & 165 \\
\hline $7: 22$ & 102 & 84 & $13: 29$ & 121 & 100 \\
\hline $7: 28$ & 156 & 107 & $13: 40$ & 111 & 90 \\
\hline $7: 36$ & 121 & 90 & $14: 01$ & 79 & 60 \\
\hline $7: 51$ & 173 & 148 & $14: 08$ & 98 & 79 \\
\hline $8: 18$ & 273 & 194 & $14: 27$ & 125 & 106 \\
\hline $8: 21$ & 169 & 141 & $14: 45$ & 141 & 124 \\
\hline $8: 26$ & 120 & 93 & $14: 48$ & 157 & 146 \\
\hline $8: 42$ & 87 & 77 & $15: 06$ & 112 & 90 \\
\hline $9: 04$ & 77 & 48 & $15: 18$ & 139 & 118 \\
\hline $9: 19$ & 62 & 39 & $15: 21$ & 119 & 96 \\
\hline $9: 30$ & 89 & 67 & $16: 01$ & 89 & 68 \\
\hline $9: 54$ & 69 & 49 & $16: 11$ & 145 & 127 \\
\hline $10: 17$ & 94 & 73 & $16: 20$ & 201 & 169 \\
\hline $10: 34$ & 107 & 85 & $16: 38$ & 221 & 182 \\
\hline $10: 55$ & 88 & 50 & $17: 06$ & 199 & 166 \\
\hline $11: 19$ & 57 & 27 & $17: 27$ & 241 & 202 \\
\hline $11: 43$ & 81 & 56 & $17: 53$ & 189 & 165 \\
\hline
\end{tabular}

Sumber : Hasil Survey (2018)

Berdasarkan hasil survei pada perlintasan madukoro raya diperoleh rata-rata waktu panjang antrian. Pada tabel 4.26 diatas dapat terlihat panjang antrian terlama terjadi pada pukul 08.18 dan 12.28. Dengan panjang 273 meter dari arah selatan dan 210 meter dari arah utara dengan jumlah sepeda motor paling dominan.

\subsubsection{Konsumsi BBM Perlintasan Madukoro Raya}

\begin{tabular}{|c|c|c|c|c|}
\hline No & $\begin{array}{c}\text { Jam Kedatangan } \\
\text { Kereta Api }\end{array}$ & $\begin{array}{c}\begin{array}{c}\text { Tundaan } \\
\text { (detik) }\end{array} \\
\end{array}$ & $\begin{array}{c}\text { Antrian } \\
(\mathrm{m})\end{array}$ & $\begin{array}{c}\text { Konsumsi BBM } \\
\text { (Liter) }\end{array}$ \\
\hline 1 & 06:00:00 - 07:00:00 & 517 & 480 & 201.54 \\
\hline 2 & 07:00:00 - 08:00:00 & 724 & 1130 & 282.61 \\
\hline 3 & 08:00:00 - 09:00:00 & 447 & 1154 & 174.88 \\
\hline 4 & 09:00:00 - 10:00:00 & 459 & 500 & 178.99 \\
\hline 5 & 10:00:00 - 11:00:00 & 345 & 497 & 134.64 \\
\hline 6 & $11: 00: 00$ - 12:00:00 & 314 & 410 & 122.51 \\
\hline 7 & $12: 00: 00$ - 13:00:00 & 339 & 1196 & 132.91 \\
\hline 8 & 13:00:00 - 14:00:00 & 499 & 1096 & 195.06 \\
\hline 9 & $14: 00: 00$ - 15:00:00 & 734 & 1115 & 286.49 \\
\hline 10 & 15:00:00 - 16:00:00 & 448 & 674 & 174.86 \\
\hline 11 & $16: 00: 00$ - 17:00:00 & 532 & 1202 & 207.99 \\
\hline 12 & $17: 00: 00$ - 18:00:00 & 354 & 1162 & 138.71 \\
\hline \multicolumn{4}{|c|}{ Total Konsumsi Bahan Bakar Minyak / jam (Liter) } & 2231.19 \\
\hline
\end{tabular}

Sumber : Hasil Survey (2018)

Berdasarkan table 2.30 di atas jumlah pengeluaran konsumsi bbm tertinggi pada pukul $14.00-15.00$ sebesar 286.49 liter sedangkan yang terendah pada pukul $11.00-12.00$ sebesar 122.51 liter.

\subsubsection{Perbandingan antara persyaratan perlintasan sebidang dengan kondisi perlintasan kereta api Madukoro}

\begin{tabular}{|c|c|c|}
\hline No & $\begin{array}{l}\text { Persyaratan } \\
\text { Perlintasan } \\
\text { Sebidang }\end{array}$ & $\begin{array}{ll}\text { Perlintasan } & \\
\text { Kereta Api } \\
\text { Madukoro }\end{array}$ \\
\hline $\bar{~} 1$ & 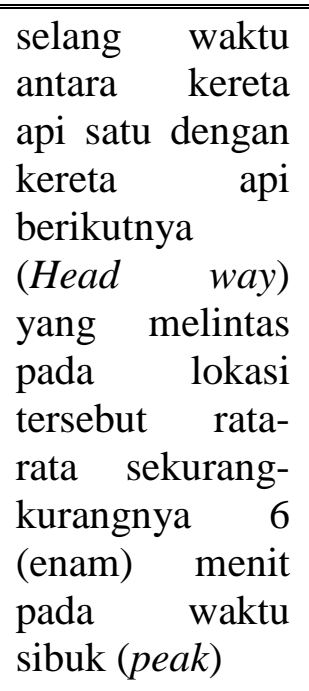 & $\begin{array}{lr}\text { selang } & \text { waktu } \\
\text { antara kereta } \\
\text { api satu dengan } \\
\text { kereta api } \\
\text { berikutnya } \\
\text { (Head way) } \\
\text { yang melintas } \\
\text { pada } \\
\text { perlintasan } \\
\text { jerakah adalah } \\
7 \text { menit }\end{array}$ \\
\hline 2 & $\begin{array}{l}\text { jarak } \\
\text { perlintasan } \\
\text { yang satu } \\
\text { dengan yang } \\
\text { lainnya pada } \\
\text { satu jalur kereta } \\
\text { api tidak kurang } \\
\text { dari } 800 \text { meter; }\end{array}$ & $\begin{array}{l}\text { jarak } \\
\text { perlintasan } \\
\text { terdekat adalah } \\
100 \text { meter }\end{array}$ \\
\hline 3 & $\begin{array}{l}\text { tidak terletak } \\
\text { pada } \\
\text { lengkungan } \\
\text { jalan kereta api } \\
\text { atau tikungan } \\
\text { jalan; }\end{array}$ & $\begin{array}{l}\text { terletak } \\
\text { kondisi } \\
\text { lurus }\end{array}$ \\
\hline 4 & $\begin{array}{l}\text { terdapat kondisi } \\
\text { lingkungan yang } \\
\text { memungkinkan } \\
\text { pandangan bagi } \\
\text { masinis kereta } \\
\text { api dari as } \\
\text { perlintasan dan }\end{array}$ & $\begin{array}{l}\text { Tidak ada } \\
\text { bangunan } \\
\text { ataupun pohon } \\
\text { yang } \\
\text { menghalangi } \\
\text { jarak pandang } \\
\text { pengguna jalan }\end{array}$ \\
\hline
\end{tabular}


bagi pengemudi

kendaraan

bermotor;

5

$\begin{array}{ll}\text { Jalan yang } & \text { Jalan } \\ \text { melintas adalah } & \text { Madukoro } \\ \text { jalan Kelas III } & \text { Raya termasuk } \\ & \text { ke dalam kelas } \\ & \text { III }\end{array}$

Sumber : Tugas Akhir Gita Mustika

Dewi Kelo, Gloryani F.N Jehudu

Dari tabel 4.36 diatas, Perlintasan Madukoro raya memenuhi 4 dari 5 persyaratan perlintasan sebidang. Persyaratan yang belum dipenuhi adalah ketentuan tentang jarak perlintasan yang satu dengan yang lainnya pada satu jalur kereta api tidak kurang dari 800 meter, sedangkan jarak perlintasan terdekat dari Jalan Madukoro Raya adalah 100 meter.

\subsubsection{Penentuan Perlintasan Sebidang Madukoro}

\begin{tabular}{|c|c|c|}
\hline No & $\begin{array}{l}\text { Penentuan } \\
\text { Perlintasan } \\
\text { Sebidang }\end{array}$ & $\begin{array}{l}\text { Perlintasan } \\
\text { Madukoro }\end{array}$ \\
\hline 1 & $\begin{array}{l}\text { Jumlah kereta } \\
\text { api yang } \\
\text { melintas pada } \\
\text { lokasi tersebut } \\
\text { sebanyak- } \\
\text { banyaknya } 25 \\
\text { kereta /hari; }\end{array}$ & $\begin{array}{lr}\text { Jumlah } & \text { kereta } \\
\text { api } & \text { yang } \\
\text { melintas } & \\
\text { sebanyak } & 88 \\
\text { kereta/hari } & \end{array}$ \\
\hline 2 & 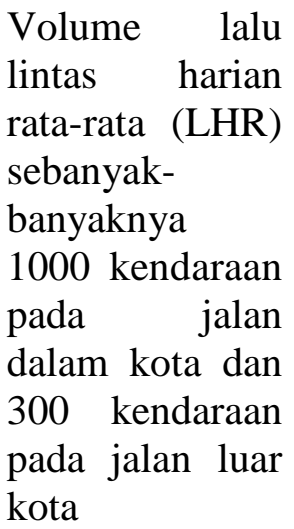 & $\begin{array}{lr}\text { Volume } & \text { lalu } \\
\text { lintas } & \text { harian } \\
\text { rata-rata } & (\mathrm{LHR}) \\
\text { sebesar } & \\
26.647,4 & \\
\text { smp/jam } & \end{array}$ \\
\hline
\end{tabular}

3 Hasil perkalian Hasil perkalian antara volume antara volume lalu lintas lalu lintas harian rata-rata harian rata- rata (LHR) dengan dengan frekuensi kereta frekuensi kereta api sebanyak- api sebanyak banyaknya 2.718.034,8 $12.500 \mathrm{smpk}$. smpk

\section{Sumber : Tugas Akhir Gita Mustika \\ Dewi Kelo, Gloryani F.N Jehudu}

Berdasarkan tabel 4.39 diatas, perlintasan Madukoro sudah memenuhi untuk menjadi perlintasan sebidang dengan palang pintu. Karena baik dari frekuensi kereta api, maupun LHR dan hasil perkalian LHR dengan frekuensi kereta api sudah memenuhi syarat sebagai perlintasan sebidang dengan palang pintu.

\subsection{Perlintasan Kokrosono}

\subsubsection{Volume Perlintasan Kokrosono}

\begin{tabular}{|c|c|c|c|c|c|c|}
\hline Waktu & $\begin{array}{c}\text { EMP } \\
\text { motor }\end{array}$ & $\begin{array}{c}\text { EMP } \\
\text { Mobil }\end{array}$ & $\begin{array}{c}\text { EMP } \\
\text { Kendaraan } \\
\text { Berat }\end{array}$ & $\begin{array}{c}\text { EMP } \\
\text { Angkutan } \\
\text { Umum }\end{array}$ & $\begin{array}{c}\text { EMP } \\
\text { Kendaraan tak } \\
\text { bermotor }\end{array}$ & $\begin{array}{c}\text { Jumlah } \\
\text { EMP }\end{array}$ \\
\hline \hline $06.00-07.00$ & 171.40 & 120.88 & 0.00 & 1.15 & 0.80 & 294.23 \\
\hline $07.00-08.00$ & 250.15 & 150.63 & 1.65 & 0.15 & 1.20 & 403.78 \\
\hline $08.00-09.00$ & 269.30 & 131.63 & 1.00 & 0.00 & 1.45 & 403.38 \\
\hline $09.00-10.00$ & 314.20 & 95.25 & 1.40 & 0.00 & 0.20 & 411.05 \\
\hline $10.00-11.00$ & 260.40 & 97.38 & 2.15 & 0.45 & 2.70 & 363.08 \\
\hline $11.00-12.00$ & 245.85 & 118.75 & 1.10 & 0.00 & 0.55 & 366.25 \\
\hline $12.00-13.00$ & 304.15 & 148.50 & 3.70 & 0.55 & 0.00 & 456.90 \\
\hline $13.00-14.00$ & 379.25 & 247.63 & 3.30 & 1.90 & 0.65 & 632.73 \\
\hline $14.00-15.00$ & 335.60 & 290.63 & 2.75 & 0.00 & 1.90 & 630.88 \\
\hline $15.00-16.00$ & 288.15 & 219.38 & 1.50 & 0.05 & 0.00 & 509.08 \\
\hline $16.00-17.00$ & 341.25 & 280.25 & 1.70 & 1.90 & 0.60 & 625.70 \\
\hline $17.00-18.00$ & 362.80 & 293.50 & 0.35 & 0.00 & 1.15 & 657.80 \\
\hline
\end{tabular}

\section{Sumber : Hasil Survey Perlintasan} Kokrosono Raya,2018

Dari data yang di peroleh pada saat survey di lapangan, dapat di peroleh hasil lalu lintas harian rata rata (LHR) diperlintasan kokrosono sebesar 11,509.65 smp/jam. Hasil perkalian LHR dengan frekuensi kereta api sebesar 1,173,984.30 smpk. Volume maksimal terjadi pada pukul 17.00 18.00 sebesar $657.80 \mathrm{smp}$. 


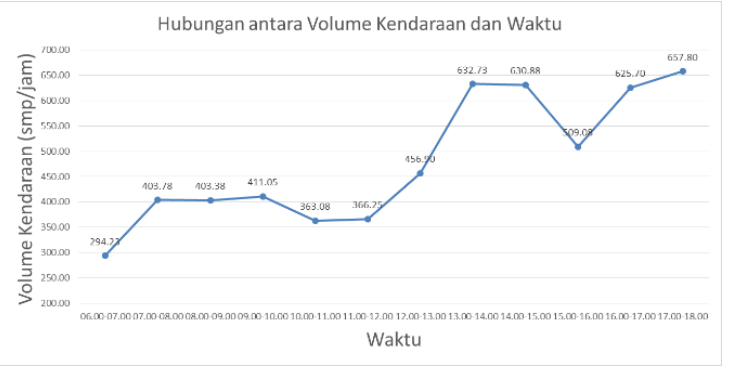

Gambar 4.12 Diagram garis Hubungan antara Volume Kendaraan dan Waktu pada Perlintasan Kokrosono Sumber : Hasil Survey Perlintasan Kokrosono,2018

\subsubsection{Tundaan Perlintasan Kokrosono}

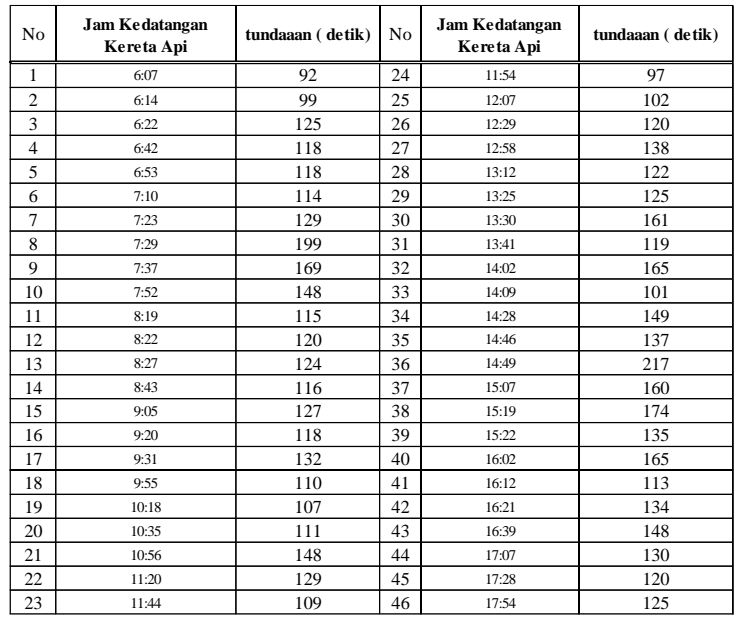

Sumber : Hasil Survey (2018)

Berdasarkan hasil survei pada perlintasan kokrosono diperoleh ratarata waktu tundaan. Pada tabel 4.31 diatas dapat terlihat tundaan terlama terjadi yaitu 217 detik pada pukul 14:49

\subsubsection{Panjang Antrian Perlintasan Kokrosono}

\begin{tabular}{|c|c|c|c|c|c|}
\hline \multirow{2}{*}{$\begin{array}{c}\text { Jam Kedatangan } \\
\text { Kereta Api }\end{array}$} & \multicolumn{2}{|c|}{ panjang antrian } & \multirow{2}{*}{$\begin{array}{c}\text { Jam Ke datangan } \\
\text { Kereta Api }\end{array}$} & \multicolumn{2}{|c|}{ panjang antrian } \\
\cline { 7 - 7 } \cline { 6 - 6 } & selatan & utara & & selatan & utara \\
\hline \hline $6: 07$ & 32 & 40 & $11: 54$ & 109 & 138 \\
\hline $6: 14$ & 45 & 54 & $12: 07$ & 147 & 134 \\
\hline $6: 22$ & 83 & 92 & $12: 29$ & 247 & 210 \\
\hline $6: 42$ & 155 & 147 & $12: 58$ & 221 & 177 \\
\hline $6: 53$ & 91 & 74 & $13: 12$ & 88 & 47 \\
\hline $7: 10$ & 134 & 125 & $13: 25$ & 149 & 116 \\
\hline $7: 23$ & 101 & 110 & $13: 30$ & 121 & 100 \\
\hline $7: 29$ & 87 & 66 & $13: 41$ & 137 & 116 \\
\hline $7: 37$ & 121 & 152 & $14: 02$ & 187 & 168 \\
\hline $7: 52$ & 173 & 154 & $14: 09$ & 98 & 79 \\
\hline $8: 19$ & 56 & 83 & $14: 28$ & 140 & 121 \\
\hline $8: 22$ & 69 & 97 & $14: 46$ & 141 & 124 \\
\hline $8: 27$ & 77 & 104 & $14: 49$ & 157 & 146 \\
\hline $8: 43$ & 48 & 58 & $15: 07$ & 112 & 90 \\
\hline $9: 05$ & 88 & 117 & $15: 19$ & 139 & 118 \\
\hline $9: 20$ & 48 & 71 & $15: 22$ & 119 & 96 \\
\hline $9: 31$ & 89 & 111 & $16: 02$ & 127 & 106 \\
\hline $9: 55$ & 69 & 89 & $16: 12$ & 145 & 127 \\
\hline $10: 18$ & 94 & 115 & $16: 21$ & 201 & 169 \\
\hline $10: 35$ & 107 & 129 & $16: 39$ & 221 & 182 \\
\hline $10: 56$ & 88 & 126 & $17: 07$ & 199 & 166 \\
\hline $11: 20$ & 66 & 96 & $17: 28$ & 241 & 202 \\
\hline $11: 44$ & 81 & 106 & $17: 54$ & 189 & 165 \\
\hline & & & & & \\
\hline
\end{tabular}

Sumber : Hasil Survey (2018)

Berdasarkan hasil survei pada perlintasan kokrosono diperoleh ratarata waktu panjang antrian. Pada tabel 4.32 diatas dapat terlihat panjang antrian terlama terjadi pada pukul 12.29. Dengan panjang 247 meter dari arah selatan dan 210 meter dari arah utara dengan jumlah sepeda motor paling dominan.

\subsubsection{Konsumsi BBM Perlintasan Madukoro Raya}

\begin{tabular}{|c|c|c|c|c|}
\hline No & $\begin{array}{c}\text { Jam Kedatangan } \\
\text { Kereta Api }\end{array}$ & $\begin{array}{c}\text { Tundaan } \\
\text { (detik) }\end{array}$ & $\begin{array}{c}\text { Antrian } \\
(\mathrm{m}) \\
\end{array}$ & $\begin{array}{c}\text { Konsumsi BBM } \\
\text { (Liter) }\end{array}$ \\
\hline 1 & 06:00:00 - 07:00:00 & 552 & 813 & 215.43 \\
\hline 2 & 07:00:00 - 08:00:00 & 759 & 1223 & 296.31 \\
\hline 3 & 08:00:00 - 09:00:00 & 475 & 592 & 185.29 \\
\hline 4 & 09:00:00 - 10:00:00 & 487 & 682 & 190.04 \\
\hline 5 & $10: 00: 00$ - 11:00:00 & 366 & 659 & 142.95 \\
\hline 6 & $11: 00: 00$ - 12:00:00 & 335 & 596 & 130.84 \\
\hline 7 & $12: 00: 00$ - 13:00:00 & 360 & 1136 & 141.02 \\
\hline 8 & 13:00:00 - 14:00:00 & 527 & 874 & 205.76 \\
\hline 9 & $14: 00: 00$ - 15:00:00 & 769 & 1361 & 300.32 \\
\hline 10 & $15: 00: 00$ - 16:00:00 & 469 & 674 & 183.03 \\
\hline 11 & $16: 00: 00$ - 17:00:00 & 560 & 1278 & 218.94 \\
\hline 12 & $17: 00: 00$ - 18:00:00 & 375 & 1162 & 146.88 \\
\hline \multicolumn{4}{|c|}{ Total Konsumsi Bahan Bakar Minyak / jam (Liter) } & 2356.81 \\
\hline
\end{tabular}

Sumber : Hasil Survey (2018)

Berdasarkan table 2.34 di atas jumlah pengeluaran konsumsi bbm tertinggi pada pukul $14.00-15.00$ 
sebesar 300.32 liter sedangkan yang terendah pada pukul 11.00 - 12.00 sebesar 130.84 liter.

\subsubsection{Perbandingan antara persyaratan perlintasan sebidang dengan kondisi perlintasan kereta api Kokrosono}

\begin{tabular}{|c|c|c|}
\hline $\mathrm{No}$ & $\begin{array}{l}\text { Persyaratan } \\
\text { Perlintasan } \\
\text { Sebidang }\end{array}$ & $\begin{array}{l}\text { Perlengkapan } \\
\text { Perlintasan } \\
\text { Kereta Api } \\
\text { Kokrosono }\end{array}$ \\
\hline $\bar{~} 1$ & $\begin{array}{lr}\text { selang } & \text { waktu } \\
\text { antara } & \text { kereta } \\
\text { api satu dengan } & \text { kereta } \\
\text { kerikutnya } \\
\text { bei } \\
\text { (Head way) } \\
\text { yang melintas } \\
\text { pada lokasi } \\
\text { tersebut rata- } \\
\text { rata sekurang- } \\
\text { kurangnya } 6 \\
\text { (enam) menit } \\
\text { pada waktu } \\
\text { sibuk (peak) }\end{array}$ & $\begin{array}{lr}\text { selang } & \text { waktu } \\
\text { antara kereta } \\
\text { api satu dengan } \\
\text { kereta api } \\
\text { berikutnya } \\
\text { (Head way) } \\
\text { yang melintas } \\
\text { pada } \\
\text { perlintasan } \\
\text { jerakah adalah } \\
7 \text { menit. }\end{array}$ \\
\hline 2 & $\begin{array}{lr}\text { jarak } & \\
\text { perlintasan } & \\
\text { yang } & \text { satu } \\
\text { dengan yang } \\
\text { lainnya pada } \\
\text { satu jalur kereta } \\
\text { api } \quad \text { tidak } \\
\text { kurang dari } 800 \\
\text { meter. }\end{array}$ & $\begin{array}{l}\text { jarak } \\
\text { perlintasan } \\
\text { terdekat adalah } \\
100 \text { meter. }\end{array}$ \\
\hline 3 & $\begin{array}{l}\text { tidak terletak } \\
\text { pada } \\
\text { lengkungan } \\
\text { jalan kereta api } \\
\text { atau tikungan } \\
\text { jalan; }\end{array}$ & $\begin{array}{l}\text { terletak } \\
\text { kondisi } \\
\text { lurus }\end{array}$ \\
\hline 4 & $\begin{array}{l}\text { terdapat kondisi } \\
\text { lingkungan } \\
\text { yang } \\
\text { memungkinkan }\end{array}$ & $\begin{array}{l}\text { Ada pohon } \\
\text { yang } \\
\text { menghalangi } \\
\text { jarak pandang }\end{array}$ \\
\hline
\end{tabular}

pandangan bagi pengguna jalan masinis kereta api dari as perlintasan dan bagi pengemudi kendaraan bermotor;

\section{Jalan yang Jalan} melintas adalah Kokrosono jalan Kelas III termasuk ke dalam kelas III

Sumber : Tugas Akhir Gita Mustika Dewi Kelo, Gloryani F.N Jehudu

Dari tabel 4.37 diatas, Perlintasan Kokrosono memenuhi 3 dari 5 persyaratan perlintasan sebidang. Persyaratan yang belum dipenuhi adalah adanya pohon yang menghalangi jarak pandang pengguna jalan dan ketentuan tentang jarak perlintasan yang satu dengan yang lainnya pada satu jalur kereta api tidak kurang dari 800 meter, sedangkan jarak perlintasan terdekat dari Jalan Kokrosono adalah 100 meter.

\subsubsection{Penentuan Perlintasan Sebidang Kokrosono}

\begin{tabular}{|c|c|c|}
\hline No & $\begin{array}{l}\text { Penentuan } \\
\text { Perlintasan } \\
\text { Sebidang }\end{array}$ & $\begin{array}{l}\text { Perlintasan } \\
\text { Kokrosono }\end{array}$ \\
\hline 1 & $\begin{array}{l}\text { Jumlah kereta } \\
\text { api yang } \\
\text { melintas pada } \\
\text { lokasi tersebut } \\
\text { sebanyak- } \\
\text { banyaknya } 25 \\
\text { kereta /hari; }\end{array}$ & $\begin{array}{lr}\text { Jumlah } & \text { kereta } \\
\text { api } & \text { yang } \\
\text { melintas } & \\
\text { sebanyak } & 88 \\
\text { kereta/hari } & \end{array}$ \\
\hline 2 & $\begin{array}{lr}\text { Volume } & \text { lalu } \\
\text { lintas harian } \\
\text { rata-rata } & \text { (LHR) } \\
\text { sebanyak- } \\
\text { banyaknya } \\
1000 \text { kendaraan } \\
\text { pada jalan }\end{array}$ & $\begin{array}{lr}\text { Volume r lalu } \\
\text { lintas } & \text { harian } \\
\text { rata-rata } & \text { (LHR) } \\
\text { sebesar } & \\
11.509,65 & \\
\text { smp/jam } & \end{array}$ \\
\hline
\end{tabular}


dalam kota dan

300 kendaraan

pada jalan luar

kota

3 Hasil perkalian antara volume

lalu lintas

harian rata-rata

(LHR) dengan

frekuensi kereta

api sebanyak-

banyaknya

$12.500 \mathrm{smpk}$.
Hasil perkalian antara volume lalu lintas harian rata- rata dengan frekuensi kereta api sebanyak $1.173 .984,3$ smpk

Sumber : Tugas Akhir Gita Mustika

Dewi Kelo, Gloryani F.N Jehudu

Berdasarkan tabel 4.40 diatas, perlintasan Kokrosono sudah memenuhi untuk menjadi perlintasan sebidang dengan palang pintu. Karena baik dari frekuensi kereta api, maupun LHR dan hasil perkalian LHR dengan frekuensi kereta api sudah memenuhi syarat sebagai perlintasan sebidang dengan palang pintu.

\section{KESIMPULAN}

1. Analisis panjang antrian dan tundaan yang pertama di perlintasan Anjasmoro raya pada pukul 14.44 WIB terjadinya puncak antrian yang begitu panjang yaitu sekitar $140 \mathrm{~m}$, pada perlintasan Madukoro Raya pada pukul 08.18 WIB juga terjadi penumpukan kendaraan di perlintasan sebidang tersebut yaitu sepanjang $273 \mathrm{~m}$, dan perlintasan Kokrosono pada saat jam makan siang atau istirahat pukul 12.29 WIB terjadi penumpukan kendaraan di perlintasan sebidang tersebut yaitu sepanjang $247 \mathrm{~m}$.

2. Analisis data yang di peroleh dari hasil survey pada perlintasan Anjasmoro Raya mengkonsumsi bbm tertinggi sebesar 276.35 liter, lalu pada perlintasan Madukoro Raya sebesar 286.49 liter, kemudian pada perlintasan Kokrosono sendiri sebesar 300.32 liter.

3. Menurut analisis persyaratan perlintasan sebidang sesuai dengan SK 770 tahun 2005, perlintasan Anjasmoro Raya memenuhi 4 dari 5 syarat, perlintasan Madukoro Raya memenuhi 4 dari 5 syarat, perlintasan Kokrosono memenuhi 3 dari 5 syarat.

4. Berdasarkan ketentuan pada SK 770 tahun 2005, pada perlintasan Anjasmoro Raya (2.580.614,4 smpk), pada perlintasan Madukoro Raya (2.718.034,8 smpk) dan pada perlintasan Kokrosono (1.173.984,3 smpk) sudah tidak memenuhi syarat sebagai perlintasan sebidang ( LHR x Frekuensi kereta api < 35.000 smpk), sehingga sebaiknya sudah ditingkatkan menjadi perlintasan tidak sebidang.

\section{DAFTAR PUSTAKA}

Lubis Royhan A. Studi Pengaruh Perlintasan Sebidang Jalan Dengan Rel Kereta Api Terhadap Karakteristik Lalulintas"(Studi Kasus: Perlintasan Kereta Api Jalan Sekip). Medan : Universitas Sumatera Utara. 
Mujahidin Muhammad I, Sumarsono A, Legowo Slamet J. Hubungan tundaan dan panjang antrian terhadap konsumsi bahan bakar akibat penyempitan jalan (Bottleneck) pada pembangunan Flyover Palur (Studi kasus : Jalan raya Palur KM 7,5). e-Jurnal Matriks Teknik Sipil Vol. 2 No. 4 tahun 2014.

http://matriks.sipil.ft.uns.ac.id/index.ph p/MaTekSi/article/view/263

Pebrianti Noffi A. 2016. Dampak Tundaan pada pengoperasian palang pintu perlintasan kereta api di jalan Timoho Yogyakarta terhadap konsumsi bahan bakar minyak. Yogyakarta : Universitas Islam Indonesia.

Peraturan Menteri 10 tahun 2011 tentang persyaratan teknis peralatan persinyalan

Peraturan Pemerintah No. 26 tahun 1985 tentang Jalan

Peraturan Pemerintah No. 43 tahun 1993 tentang Prasarana dan lalu lintas jalan

Peraturan Pemerintah No.56 tahun 2009 tentang penyelenggaraan perkeretaapian

Sitorus Fernando P, Surbakti Medis S. Studi pengaruh Perlintasan Sebidang jalan dengan rel kereta api terhadap karakteristik lalu lintas di perlintasan kereta api jalan Sisingamangaraja Medan. Medan : Universitas Sumatera Utara.

SK.770/KA.401/DRJD/2005, (2005), "Peraturan Direktur Jenderal Perhubungan Darat Nomor tentang Pedoman Teknis Perlintasan
Sebidang Antara Jalan dengan Jalur Kereta Api"

UU No. 22 tahun 2009 tentang Lalu Lintas dan Angkutan Jalan

UU No. 23 tahun 2007 tentang Perkeretaapian 